\title{
PENGALAMAN KELUARGA MERAWAT PENDERITA TB PARU DI KOTA PONTIANAK
}

\section{(Family Experience of Caring People with Pulmonary TB in Pontianak City)}

\author{
Selvy Rahmayuni*, Arina Nurfianti**, Muhammad Ali Maulana*** \\ * Mahasiswi Prodi Keperawatan Fakultas Kedokteran Universitas Tanjungpura, Pontianak \\ rahmayuniselvy@gmail.com **Dosen Keperawatan Fakultas Kedokteran Universitas Tanjungpura, Pontianak \\ arina.nurfianti@gmail.com ***Dosen Keperawatan Fakultas Kedokteran Universitas Tanjungpura, Pontianak \\ ali.maulana85@gmail.com
}

\begin{abstract}
ABSTRAK
Latar Belakang : Tuberkulosis merupakan penyakit menular yang disebabkan oleh bakteri Mycobacterium tuberculosis. Upaya yang dilakukan pemerintah dalam menangani tuberkulosis dengan membuat program Adopsi dari Strategi Penanggulangan Tuberkulosis (DOTS). Namun, adanya pengalaman dan dukungan keluarga dalam perawatan serta pengobatan dapat mempengaruhi proses penyembuhan pada penderita TB Paru.
\end{abstract}

Tujuan : Penelitian ini bertujuan untuk mengeksplorasi pengalaman keluarga serta upaya yang dilakukan keluarga dalam merawat penderita TB Paru.

Metode : Penelitian kualitatif deskriptif menggunakan metode wawancara in-depth interview (wawancara mendalam) dengan pendekatan fenomenologi. Penelitian dilakukan dengan 4 orang partisipan yang menjadi anggota keluarga yang merawat penderita TB Paru di Kota Pontianak. Sampel diambil menggunakan purposive sampling (variasi maksimal). Analisa data menggunakan Miles and Huberman dengan unsur reduksi data, penyajian data dan penarikan kesimpulan.

Hasil : Hasil penelitian ini didapatkan tiga tema, yaitu persepsi keluarga bahwa TB merupakan penyakit yang berkepanjangan dan mudah menular, pengalaman keluarga yang positif dan efek samping yang berdampak pada multisistem.

Kesimpulan : Persepsi yang dimiliki keluarga mempengaruhi proses perawatan yang membuat keluarga takut akan tertular. Namun, adanya pengalaman keluarga diharapkan mampu membantu proses perawatan dan pengobatan baik dengan memberikan dukungan maupun membantu proses perawatan sehingga tidak menimbulkan efek samping yang signifikan pada penderita selama pengobatan.

Kata Kunci : TB Paru, Keluarga, Persepsi, Pengalaman, Efek Samping 


\begin{abstract}
Background: Tuberculosis is an infectious disease caused by Mycobacterium tuberculosis bacteria. The effort made by the government dealing with Tubercolusis by creating an adoption program from the tuberculosis prevention strategy (DOTS). However, family experience and support of caring and treatment can influence the healing process to pulmonary TB Patient.
\end{abstract}

Aim: This study aims to explore the family experiences and efforts that the family made in a caring patient with pulmonary $T B$.

Method: Descriptive qualitative study using the in-depth interview method with a phenomenology approach. This research was conducted by using 4 participants who were family members of people dealing with lung TB in Pontianak City. The participants were recruited using purposive sampling (maximum variation). Data were analyzed by Miles and Huberman with elements of data reduction, data presentation, and concluding.

Result: The result of this research found three themes, that is the family's perception that TB is a prolonged and easily contagious disease, positive family experiences and side effects that have a multisystem impact.

Conclusion: Perception that minded by the family can cause the nursing process that makes the family afraid of being infected. However, the family experience is expected could help the process of nursing and treatment both by providing support and assisting the treatment process so that it does not cause significant side effects on the patient during treatment.

Keyword: Pulmonary TB, Family, Perception, Experience, Side Effects

\section{PENDAHULUAN}

Tuberkulosis (TB) adalah salah satu penyakit infeksi yang disebabkan oleh bakteri dari Mycobacterium tuberculosis. Bakteri dari Mycobacterium tuberculosis menyerang bagian paru-paru sebagai tempat infeksi primer. Selain itu, bakteri ini dapat juga menyerang bagian kulit, kelenjar limfe, tulang, serta selaput otak. TB menular melalui droplet infeksius yang terinhalasi oleh orang sehat. ${ }^{1}$

Fenomena dengan pengalaman merawat penderita TB Paru dapat mempengaruhi keberhasilan perawatan. Salah satu upaya yang pemerintah lakukan untuk memerangi penyakit Tuberkulosis Paru pada saat ini adalah Adopsi dari
Strategi Penanggulangan Tuberkulosis (DOTS) dalam bentuk jangka pendek dengan pengobatan diawasi langsung. Meskipun pemerintah telah melakukan strategi penanggulangan tuberkulosis paru tetapi masih ada banyak pasien TB paru ditemukan. Hal ini disebabkan oleh pengetahuan dan sikap seseorang yang kurang di antara komunitas. Dalam hal ini pengetahuan merupakan hal penting dalam memberikan wawasan tentang sikap dan tindakan seseorang. ${ }^{2}$

Tuberkulosis Paru di Indonesia tercatat 391 per 100.000 penduduk dengan angka kematian 42 per 100.000 penduduk. Indonesia merupakan salah satu negara yang kasus Tuberkulosis terbesar selain India, China, Philippina dan Pakistan 
berdasarkan data dari WHO. ${ }^{1}$ Penyakit TB Paru yang terjadi saat ini merupakan salah satu penyebab kematian diseluruh dunia.

Pengalaman merupakan suatu peristiwa atau kejadian yang pernah dilakukan dan dialami seseorang. Oleh karena itu, peneliti menggunakan metode penelitian kualitatif untuk dapat mengetahui pengalaman partisipan secara keseluruhan. Pada penelitian sebelumnya, masih belum terdapat penelitian kualitataif mengenai pengalaman keluarga yang merawat penderita TB Paru. Pada penelitian ini, peneliti bertujuan untuk mencari fenomena tentang pengalaman keluarga sehingga peneliti menggunakan pendekatan fenomenologi. Peneliti tidak membatasi pendapat partisipan dan tidak menggiring jawaban partisipan sehinga peneliti menggunakan penelitian fenomenologi transenden.

\section{METODE}

Penelitian ini termasuk dalam penelitian kualitatif deskriptif dengan metode wawancara mendalam (in-depth interview). Pendekatan yang digunakan pada penelitian ini adalah pendekatan fenomenologi transenden.

Penelitian ini akan dilaksanakan di rumah penderita TB Paru yang tercatat di Unit Pengobatan Pelayanan Kesehatan Paru-Paru Kota Pontianak. Adapun alasan pemilihan tempat ini ialah berdasarkan penemuan masalah yang terdapat di lapangan, masalah yang ditemukan ialah mengenai pengalaman anggota keluarga merawat pasien TB Paru. Penelitian dilaksanakan mulai bulan April hingga bulan Oktober 2019. Pengambilan data penelitian akan dilaksanakan pada bulan September 2019.

Partisipan pada penelitian ini telah dipilih berdasarkan ktriteria inklusi yang telah terpenuhi. Partisipan yang tidak memenuhi kriteria inklusi tidak diikutsertakan menjadi partisipan dalam penelitian. Partisipan dalam penelitian ini berjumlah 4 orang partisipan. Kriteria Inklusi dalam penelitian ini adalah anggota keluarga yang menjadi caregiver dengan penderita, anggota keluarga yng tinggal satu rumah dengan penderita, dan anggota keluarga yang berperan sebagai pengawas minum obat (PMO).

Pada penelitian ini peneliti menggunakan metode purposive sampling dengan variasi maksimal. Instrumen yang digunakan dalam penelitian yang berkaitan dengan analisis pengalaman keluarga merawat penderita TB Paru di Kota Pontianak adalah peneliti itu sendiri dengan menggunakan alat bantu seperti perekam suara (aplikasi telephone seluler), pedoman wawancara mendalam (in-depth interview), alat tulis dan kamera. Metode dalam pengumpulan data yang digunakan pada penelitian ini adalah dengan melakukan wawancara semiterstruktur (semi structure interview). ${ }^{3}$

Model analisis data yang digunakan dalam penelitian ini yaitu peneliti mengikuti konsep yang diberikan Miles and Huberman dengan menggunakan tiga unsur analisis data penelitan yaitu reduksi data, penyajian data dan penarikan kesimpulan. Validitas dan reliabilitas dalam penelitian ini ditetapkan dengan menggunakan kriteria keabsahan data. Untuk menetapkan keabsahan suatu data, diperlukan tehnik pemeriksaan yang didasarkan 4 kriteria yaitu uji creadibility, confirmability, dependability, dan transferability.

\section{HASIL}

\section{Gambaran Karakteristik Partisipan}

Peneliti telah melakukan wawancara dengan jumlah partisipan seluruhnya adalah 4 orang yang terdiri dari orangtua, anak, dan menantu dari penderita TB Paru. Usia partisipan berkisar antara 23 tahun hingga 54 tahun.

\section{Partisipan $1(\mathrm{P} 1)$}

Partisipan 1, usia 54 tahun, jenis kelamin laki-laki, beragama islam, bekerja sebagai swasta, pendidikan terakhir Diploma, dan 
memiliki hubungan orang tua atau ayah dari penderita.

2. Partisipan $2(\mathrm{P} 2)$

Partisipan 2, usia 23 tahun, jenis kelamin perempuan, beragama islam, pendidikan terakhir Diploma IV, dan memiliki hubungan anak kandung dari penderita.

3. Partisipan 3 (P3)

Partisipan 3, usia 39 tahun, jenis kelamin perempuan, beragama islam, bekerja sebagai ibu rumah tangga, pendidikan terakhir SMA, dan memiliki hubungan menantu dari penderita.

4. Partisipan 4 (P4)

Partisipan 4, usia 29 tahun, jenis kelamin perempuan, beragama islam, bekerja sebagai ibu rumah tangga, pendidikan terakhir S1 MIPA, dan memiliki hubungan anak kandung dari penderita.

\section{Analisis Tematik}

Penelitian ini menggunakan metode analisa data Miles and Hauberman yang terbagi menjadi tiga tahap yaitu tahap reduksi data, penyajian data, dan penarikan kesimpulan. Sehingga tema yang didapatkan dari hasil wawancara dengan 4 orang partispan berdasarkan hasil analisis didapatkan tiga tema yaitu persepsi keluarga bahwa TB merupakan penyakit yang berkepanjangan dan mudah menular, pengalaman keluarga yang positif, dan efek samping yang berdampak pada multisystem.

\section{Persepsi keluarga bahwa TB merupakan penyakit yang berkepanjangan dan mudah menular}

Persepsi keluarga bahwa TB merupakan penyakit yang berkepanjangan dan mudah menular merupakan tujuan penelitian yang terjawab dalam 4 kategori yaitu keyakinan bahwa batuk berkepanjangan merupakan gejala awal TB, persepsi bahwa TB merupakan penyakit yang menular, respon negatif yang diberikan lingkungan terhadap penderita, dan tidak ada aspek dukungan sosial dari lingkungan sekitar mengenai penderita.

Persepsi keluarga bahwa TB merupakan penyakit yang berkepanj ngan dan mudah menular dilihat dari keyakinan keluarga bahwa batuk yang panjang adalah awal penyakit TB Paru yang menimbulkan respon negatif seperti dukungan sosial dari lingkungan sekitar pada keluarga.

Hal ini sesuai dengan pernyataan salah satu partisipan yaitu:

".....itukan merupakan suatu penyakit yang kontennye tuh bise sebagai penyakit yang menular begitukan.....(P1)"

“.....karna juga lingkungan seperti kotor banyak kuman yang buat fisik badan kite jadinye tu ngedrop pas ade orang kenak tb paru akhirnye nular.....(P2)"

“....taunye cuman tbc batuk-batuk lama gitu, pengobatannye 6 bulan gitukan.....(P3)”

'.....penyakit batuk yang lamak berarti die memang kenak kuman.....(P4)”

".....tetangga kayak merase tb paru tu kayak penyakit yang menular yang kayaknye jahat gitukan.....(P2)"

".....keluarga menjauh dak mau tinggal disini.....(P3)"

\section{Pengalaman keluarga yang positif}

Dari hasil wawancara dengan partisipan, terdapat pengalaman keluarga yang kearah positif karena berdasarkan sub kategori perasaan takut anggota keluarga akan tertularnya penyakit yang sama, peran keluarga dan lingkungan dalam proses perawatan mentransformasikan bentuk usaha penyembuhan dan minimalnya hambatan yang dirasakan oleh keluarga.

Pernyataan informan diatas pengalaman keluarga yang positif dapat 
dilihat dari pengalaman keluarga yang merawat penderita TB Paru dengan persepsi perasaan takut kemudian ditemukan tidak ada keluhan berarti dari keluarga yang didukung oleh minimnya hambatan yang dirasakan keluarga.

Hal ini dapat dilihat dari salah satu kutipan partisipan:

".....kalau kite merase was was lah kan dan merase kaget....Kalau dirumah konsumsi obatnye memang harus rutin....kalo diluar usahakan pake masker terus die kalau beradaptasi dengan kawannye tu jage jarak.... (P1)"

".....awalnye sedih ye pasti... pokoknye dibersihkan sebersih-bersihnye lah kalok bise rumah sih yang pasti harus ee....lingkungan sekitar juga seminggu sekali... dipelayanan kesehatan paru ye damping diantar.... (P2)”

".....yang pasti sih takut terjangkiy itu ada....kalau disekitar rumah paling-paling ye jangan jak buang dahak-dahak sembarangan....mendampingi kalo disuruh kontrol tiap bulan... (P3)"

".....syok petame khawatir takut juga...awal-awalnye selamak 2 bulan tu intensif pake masker...tiap hari dibersihin kamarnye...ngingatkan bapak kontrol terus... (P4)"

\section{Efek samping yang berdampak pada multisystem}

Dari hasil wawancara dengan partisipan, terdapat efek samping yang berdampak pada multisystem yang berdasarkan adanya sub kategori gangguan rasa nyaman, perubahan berat badan, peningkatan nafsu makan, perubahan warna urin dan gangguan sirkulasi ekstrimitas. Pernyataan ini sesuai dengan efek samping penyakit dan pengobatan dapat dinyatakan sebagai efek samping yang multisistem dengan berjalan proses perawatan dan pengobatan terjadi perubahan nafsu makan yang membuat perubahan berat badan meski diawal penyakit penderita mengalami menurunan berat badan yang drastis yang disertai adanya alergi gatal-gatal dan nyeri serta perubahan warna urin saat mengkonsumsi obat.

"....punya kayak benjolan dileher ada nyeri...obatnye warne merah tu kan [aling buang air kecilnye tu nanti merah... (P1)",

".....alergi obatnye gatal-gatal tu....berat badanye malah nambah teros.... (P2)"

".....sakit pinggang sering...kencingnye merah itu jak sih....sama lutut sering nyeri.... (P3)"

".....berat badannye turun drastis...sama lbapak malah kuat makan makin kesini...waktu mengkonsumsi obat yang merah itu air seninya ikutan merah.... (P3)"

Salah satu partisipan (P3) juga mengatakan bahwa penderita mengalami bengkak-bengkak pada kaki saat proses pengobatan.

".....kayaknye bapak ini, mudah bengkak bengkak kakinye.... (P3)"

\section{PEMBAHASAN}

Peneliti mengidentifikasi tiga tema yang merupakan hasil analisis dari hasil penelitian. Adapun tema yang didapat dari hasil analisis yakni, persepsi keluarga bahwa TB merupakan penyakit yang berkepanjangan dan mudah menular, pengalaman keluarga yang positif, dan efek samping yang berdampak pada multisystem.

\section{Persepsi keluarga bahwa TB merupakan penyakit yang berkepanjangan dan mudah menular}

Berdasarkan dari hasil penelitian data partisipan yang telah dipaparkan sebelumnya, banyak faktor yang menjadi penghambat dalam pemberian imunisasi 
MR. Faktor-faktor yang menjadi penghambat imunisasi MR terbagi menjadi empat kategori yaitu isu-isu dan penolakan imunisasi, ketakutan akan jarum suntik, penyampaian informasi yang kurang efektif, dan tidak adanya dukungan keluarga.

Persepsi menurut Wahyuni, Indarwati, \& Sugiharto (2015) adalah sebuah proses seperti pengorganisasian, penginterprestasian terhadap rangsang yang diterima oleh organisme atau individu sehingga merupakan sesuatu yang berarti dan merupakan aktivitas yang terintegrasi dalam diri individu. Persepsi merupakan proses diterimanya rangsang melalui panca indra yang didahukui oleh perhatian sehingga individu mampu mengetahui, mengartikan dan menghayati tentang hal yang diamati baik. Oleh karena itu penginderaan orang akan mengaitkan dengan stimulus, sedangkan dengan persepsi orang akan mengaitkaan dengan objek, dari persepsi individu akan menyadari tentang keadaan disekitarnya dan juga keadaan diri sendiri. ${ }^{4}$

Berdasarkan dari hasil wawancara terhadap informan bahwa persepsi TB Paru adalah penyakit yang menyebabkan penderitanya batuk-batuk panjang, bersifat menular karena nanti bisa menular dan berbahaya sehingga orang-orang suka menjauhi. TB Paru juga merupakan penyakit infeksi pada paru-paru yang dapat menyerang di semua segala usia tanpa terkecuali serta penyakit ini juga bisa menyebabkan badan menjadi kurus karena menurut partisipan batuk-batuk yang dialami penderita yang tidak berhenti sehingga membuat perubahan pada fisik penderita TB Paru.

Gejala-gejala awal dari penyakit Tuberkulosis umumnya sesuai dengan pernyataan Kemenkes (2018) adalah batuk produktif yang berkepanjangan lebih dari 3 minggu, sesak nafas, nyeri dada, anemia/kurang darah, batuk darah, rasa lelah, berkeringat di malam hari. ${ }^{5}$ Menurut
Jaji (2010) TB paru merupakan suatu penyakit dengan gejala batuk berkepanjangan dan mengeluarkan dahak berwarna kekuningan, kadang-kadang dahak bercampur darah, batuk darah, lelah, demam. Kehilangan nafsu makan dan berat badan turun. ${ }^{6}$

Pengetahuan tentang penyakit TB berdasarkan hasil wawancara dengan keluarga pasien yang mempunyai anggota keluarga yang menderita yaitu penyakit TB Paru disebabkan kuman. Menurut Wahyudi (2010) kuman TB paru dapat keluar bebas di udara saat penderita batuk, penularan terjadi karena kuman dibatukkan atau di bersinkan sehingga muncul gejala yang ditandai dengan batuk-batuk berdahak disertai darah, penyakit yang menyerang paru-paru, menular dengan percikan ludah, nafsu makan menurun, badan kurus, dan penyakit TB dapat disembuhkan dengan pengobatan yang tepat dan teratur. ${ }^{7}$

Apabila keluarga sudah memahami TB Paru lebih jelas, hal ini diharapkan membuat persepsi keluarga terhadap penyakit TB Paru yaitu dapat menular ke anggota keluarga lainnya dan dapat dicegah dengan cara memisahkan makanan dengan penderita TB Paru, barang terutama alat makan dipisahkan dengan penderita TB Paru, menghindari penderita TB Paru saat pasien batuk untuk menghindari pencikan langsung, dan menghindari penularan melalui dahak pasien penderita TB Paru sehingga diharapkan pasien dengan TB Paru tidak membuang dahak batuknya sembarangan.

Faktor yang mendukung persepsi keluarga yang memandang TB merupakan penyakit yang berkepanjangan dan menular adalah respon negatif dan kurangnya dukungan sosial. Respon negatif terhadap penyakit TB paru akan menyebabkan penderita takut dan menolak sehingga timbul keinginan untuk mencari pengobatan. Selain itu dari diagnosis penderita TB paru, akan mempengaruhi 
kepatuhan penderita sendiri untuk kontrol kesehatan medis dan minum obat. Berdasarkan penyataan dari Nurhidayati \& Fitrianingrum (2016) faktor psikososial berperan dalam pembentukan stigma terhadap penderita oleh lingkungan dan keluarga. Stigma yang diterima menyebabkan penderita ketakutan terhadap isolasi sosial dan dapat menunda untuk mencari pengobatan. ${ }^{8}$

Penelitian menurut Hendiani, Sakti, \& Widayanti (2014) bagi para penderita tuberkulosis (TB) yang belum ataupun telah sembuh dari penyakitnya, tentu saja tidak mudah untuk bisa kembali melakukan aktifitas-aktifitas seperti semula sebelum mengidap penyakit tuberkulosis. Hal ini tentunya membutuhkan banyak dukungan dari orang-orang di sekitarnya dan bagaimana penderita bisa memaknai lebih dalam apa yang sudah terjadi dalam hidupnya. Individu penderita tuberkulosis biasanya kurang memiliki makna hidup yang berarti karena merasa kurang mendapatkan dukungan sosial dari lingkungan disekitarnya akibat sikap yang diterimanya yakni dikucilkan dalam keluarga dan lingkungan disekitarnya serta menganggap dirinya kurang mampu untuk melakukan sesuatu yang bermanfaat atau merasa kurang produktif karena mengidap penyakit TB Paru akibat individu memiliki tingkat efikasi diri yang kurang di dalam dirinya. Kebermaknaan hidup seseorang dapat dipengaruhi oleh dua faktor yakni faktor internal dan faktor eksternal. Faktor internal disini yaitu efikasi diri sendiri, sedangkan faktor eksternalnya yaitu dukungan sosial. ${ }^{9}$

Dukungan sosial cukup berpengaruh terhadap kebermaknaan hidup. Hal ini dijelaskan Sedjati (2013) bahwa motivasi, informasi, pemenuhan yang diberikan terutama oleh keluarga cukup berpengaruh untuk individu yang bersangkutan. Individu memperoleh dukungan dalam menjalankan aktivitas sehari-hari dan aktualisasi diri sehingga kebutuhan akan keberartian atau kebermaknaan dalam hidupnya terpenuhi. Individu yang memperoleh dukungan sosial dengan baik dari keluarga dan lingkungan sosialnya akan lebih bersemangat dalam mengatur hidupnya untuk berusaha lebih baik, untuk penderita tuberkulosis misalnya dukungan sosial dapat membantu individu untuk berjuang mendapatkan kesembuhan dan menjalankan aktivitas normalnya seharihari secara baik. Sedangkan individu yang kurang mendapatkan perhatian, arahan, informasi dari keluarga akan menjadi kurang bersemangat dalam mengatur hidupnya. ${ }^{10}$

Apabila individu memperoleh dukungan sosial yang tinggi dari keluarga dan lingkungan sosialnya, yang dapat berupa semangat, informasi, penyediaan sarana dan prasarana, maupun reinforcement maka individu akan merasa keberadaannya berarti atau hidupnya bermakna. Sebaliknya apabila individu kurang mendapat dukungan sosial dari keluarga dan lingkungan sosialnya, maka individu yang bersangkutan menjadi merasa kurang berarti atau kurang memiliki kebermaknaan dalam hidupnya karena individu tidak mendapatkan penerimaan yang baik dari lingkungan di sekitarnya.

Pada kasus yang sering terjadi di masyarakat, Individu penderita tuberkulosis paru mendapatkan stigma lingkungan, isolasi sosial yang terkadang terdapat penolakan terhadap pasien oleh lingkungan dan keluarga. Menurut Nurhidayati \& Fitrianingrum (2016) dukungan sosial yang paling utama berasal dari dukungan keluarga, karena dukungan keluarga memegang peranan penting dalam kehidupan pasien penderita tuberkulosis agar berjuang untuk sembuh, selalu berpikir maju, dan selalu berkembang dengan rasa optimisme yang dimilikinya dan menjadikan hidupnya lebih bermakna. Hal yang dapat ditimbulkan dari kurangnya mendapatkan 
dukungan sosial dari keluarga dan lingkungannya antara lain yaitu gangguan jiwa yang komorbid dengan penyakit tuberkulosis. Gangguan jiwa yang bisa saja menjadi komorbiditi tuberkulosis meliputi depresi, gangguan penyesuaian, anxiety, hilangnya sebuah arti dan tujuan hidup, melemahnya produktifitas, fobia dan lainnya. ${ }^{8}$ Dengan dukungan sosial yang baik dari lingkungan, individu diharapkan merasa diterima, dicintai, dan diharapkan sehingga merasa memiliki makna hidup yang baik. Sebaliknya apabila dukungan sosial penderita kurang baik, dikhawatirkan individu penderita TB sendiri akan merasa tidak memiliki makna hidup yang berarti.

\section{Pengalaman keluarga yang positif}

Hasil wawancara terhadap informan bahwa perasaan yang dimiliki keluarga, peran keluarga dalam proses perawatan serta hambatan yang minim merupakan pengalaman positif bagi keluarga yang merawat penderita TB Paru karena tidak terdapat keluhan berarti dari keluarga dan didukung penuh dengan mekanisme koping yang baik.

Keluarga memang memegang peranan penting dalam semua level pencegahan penyakit di lingkungan keluarga. Dalam pencegahan primer keluarga dapat mempengaruhi pemilihan gaya hidupnya yang dapat mencegah penyakit. Hal penting yang mempengaruhi kesehatan menurut Hendiani, Sakti \& Widayanti (2014) yaitu perilaku pencegahan penyakit dan perilaku pemulihan kesehatan. Perilaku pencegahan penyakit pada keluarga dipengaruhi oleh pengetahuan dan sikap dukungan. ${ }^{9}$ Dukungan keluarga yang diterima penderita penyakit TB dipengaruhi oleh penilaiannya terhadap peran keluarga sendiri dalam mendorong kesembuhan. Terlebih lagi peran keluarga sebagai PMO, keluarga harus mendorong kesembuhan penderita dengan baik. Persepsi terhadap dukungan keluarga sebagai Pengawas
Minum Obat (PMO) adalah pandangan dan penilaian penderita TB terhadap interaksi dengan keluarga berupa informasi, perhatian, dorongan dan bantuan dari PMO sehingga memunculkan kualitas hubungan yang dapat mempengaruhi kesembuhan penderita. Keluarga sebagai PMO dapat mempertahankan dukungan yang diberikan pada penderita TB. Dukungan dari keluarga seharusnya dapat memotivasi penderita dalam melakukan pengobatan selama jangka waktu 6-9 bulan.

Dukungan keluarga sebagai PMO menyatakan bahwa rata-rata keluarga yang merawat penderita TB menunjukkan pengalaman positif dalam mendukungan keluarganya sendiri sebagai PMO. Berkaitan dengan kondisi tersebut, menurut Nurhidayati \& Fitrianingrum (2016) terdapat beberapa fakta di lapangan yang menjelaskan kondisi pengalaman keluarga sebagai PMO berada pada kategori positif. ${ }^{8}$ Bentuk dukungan yang tersedia dapat diperoleh dari hasil wawancara setelah penelitian dengan subjek mengatakan bahwa keluarga atau PMO sering mendampingi dan mengawasi penderita saat melakukan pengobatan, menyiapkan obat di meja untuk segera diminum, dan membantu mengatasi efek samping. Adanya rutinitas keluarga dalam mendukung anggota keluarganya yang sakit memiliki hubungan terhadap kesehatan fisik dan mental yang lebih baik.

Purwanto (2017) menyatakan bahwa sikap keluarga sangat menentukan keberhasilan pengobatan. Terlebih dalam mencegah penularannya, karena jika sikap keluarga penderita yang terdiagnosa TB paru mengerti apa yang sebenarnya dia lakukan maka secara otomatis keluarga juga bisa dan mampu melindungi dirinya serta anggota keluarga lainnya. ${ }^{11}$ Jika perilaku yang diberikan baik maka akan membawa dampak positif bagi pencegahan penularan Tuberkulosis. Dukungan yang diberikan keluarga berupa intervensi kepada penderita yang dapat memberi rasa 
nyaman dalam melakukan pengobatan. Intervensi yang diberikan keluarga adalah nasihat dan pendampingan subjek dalam melakukan pengobatan. Dukungan ini dapat mempengaruhi penderita dan keluarga yang merawat penderita TB dalam menghadapi tantangan serta hambatan dalam masa pengobatan.

Berdasarkan hasil penelitian tindakan yang telah dilakukan keluarga dalam upaya pencegahan penularan TB Paru adalah membuka jendela rumah, membersihkan pekarangan rumah, mengingatkan pasien penderita TB Paru untuk menutup mulut saat batuk, menyiapkan tempat khusus untuk penderita TB Paru membuang dahak, dan menyiapkan segala kebutuhan sehari-hari serta memperhatikan lingkungan sekitar. Upaya ini diharapkan bentuk perhatian dan rasa empati dari lingkungan keluarga dan sosial sekitar penderita kepada penderita yang dilakukan dengan sepenuh hati.

\section{Efek samping yang berdampak pada multisystem}

Hasil wawancara yang dilakukan terhadap informan ditemukan adanya efek samping yang berdampak mulitisistem karena meliputi efek samping yang positif dan efek samping yang negatif. Efek samping yang positif dilihat dari sistem pencernaan penderita yang disampaikan oleh partisipan yaitu terjadi peningkatan nafsu makan dan peningkatan berat badan. Sedangkan efek samping yang negatif terdapat gangguan rasa nyaman yaitu gatal-gatal dari reaksi alergi, perubahan warna urin yang signifikan, dan gangguan sirkulasi ekstrimitas seperti edema pada penderita TB Paru.

Sari, Yuniar, \& Syaripuddin (2014) menyatakan perubahan berat badan merupakan keluhan efek samping yang paling terjadi dan dirasakan oleh penderita saat minum obat TB paru. Gejala ini terjadi lebih banyak pada pasien yang melakukan pengobatan pada tahap intensif dibandingkan dengan tahap lanjutan karena pada fase awal pasien harus mengkonsumsi banyak macam obat sehingga dapat mengganggu proses pencernaan. Pada pasien TB Paru salah satu OAT yang digunakan adalah rifampisin. Rifampisin merupakan antibiotik semisintetik yang mempunyai efek bakterisid terhadap mikobakteri dan organism gram positif. Pada penggunaan dosis tinggi juga lebih efektif terhadap organisme gram negatif. Mekanisme kerja Rifampisin yaitu dengan menghambat sintesa RNA dari mikobakterium. Rifampisin memiliki efek samping gangguan gastrointestinal (saluran cerna) seperti rasa panas pada perut, sakit epigastrik, mual, muntah, anoreksia, kembung, kejang perut dan diare sehingga penderita dari TB Paru kesulitan untuk mengkonsumsi dan mencerna makanan yang membuat terjadinya penurunan berat badan diawal penggunaan OAT. Pada keluarga yang sedang merawat penderita TB sebaiknya menganjurkan penggunaan obat yang diminum sebelum tidur karena bertujuan untuk mengurangi keluhan yang berhubungan dengan pencernaan karena penggunaan obat TB paru. ${ }^{12}$

Berdasarkan penelitian yang dilakukan, peneliti memilih partisipan dan penderita yang sudah melakukan pengobatan lebih dari 2 bulan sehingga ditemukan hasil yang dinyatakan oleh partisipan bahwa penderita mengalami peubahan nafsu makan yang meningkat setelah melakukan proses pengobatan selama lebih dari 2 bulan. Menurut pernyataan dari Puspita, Christinto, \& Yovi (2016) hal ini bisa terjadi diakibatkan infeksi dari bakteri Mycobacterium Tuberculosis berkurang seiring pengobatan yang menyebabkan produksi pirogen endogen berkurang sehingga produksi leptin yang dapat mempengaruhi supresi nafsu makan juga menurun. ${ }^{13}$ Terjadinya peningkatan nafsu makan ini menjadikan efek samping yang positif bagi penderita 
meski dengan proses pengobatan yang sudah berlangsung lebih dari 2 bulan.

Pada penelitian yang dilakukan ini partisipan mengatakan bahwa penderita mengalami nyeri sendi saat pengobatan berlangsung. Nyeri sendi ini dapat terjadi akibat pemberian OAT jenis pirazinamid. Pirazinamid memiliki efek samping seperti nyeri sendi dan pegal. Menurut PDPI (2011) hal ini kemungkinan disebabkan berkurangnya ekskresi dan penimbunan asam urat. Kadang-kadang terjadi reaksi demam, mual, dan reaksi kulit. ${ }^{14}$

Selain efek samping positif juga ditemukan efek samping negatif pada penderita dengan TB Paru yang disampaikan langsung oleh partisipan dalam wawancara. Efek samping yang ditimbulkan berupa gangguan rasa nyaman yaitu gatal-gatal dari reaksi alergi, perubahan warna urin yang signifikan, dan gangguan sirkulasi ekstrimitas.

Berdasarkan penelitian Wiyati, Irawati, \& Budiyono (2014), semua jenis OAT menimbulkan efek samping gatal. Jika penderita TB dalam pengobatan OAT mulai mengeluh adanya gatal-gatal maka singkirkan dulu kemungkinan penyebab lainnya. Efek samping seperti berupa gatal dan kekusaman di kulit ini tidak dialami oleh semua pasien karena hal ini tergantung pada sensitivitas kulit pasien. Keluhan efek samping berupa gatal dan kekusaman ini bisa saja timbul akibat pemakaian isoniazid dan fotosensibilisasi dengan reaksi kulit menjadi kusam cokelat atau merah akibat pirazinamida. Dalam menangani efek samping yang terjadi ini dapat dianjurkan untuk diberikan anti histamin, sambil meneruskan penggunaan OAT dengan pengawasan ketat. Gatalgatal tersebut pada sebagian pasien bisa saja menghilang, namun pada sebagian pasien juga malah terjadi kemerahan pada kulit. ${ }^{15}$

PDPI (2011) menjelaskan pada penderita dengan TB Paru yang saat ini menggunakan OAT akan mengalami perubahan pada warna urin yang berubah menjadi warna merah muda. Keluhan seperti ini dapat terjaddi akibat efek dari penggunaan OAT dari rifampisin yang merupakan salah satu komponen utama dari obat anti tuberkulosis. Dalam hal ini keluarga dan penderita tidak perlu diberi apa-apa, tetapi cukup diberikan informasi dan penjelasan kepada keluarga serta pasien mengenai perubahan warna urin. ${ }^{14}$

Efek samping yang juga ditemukan dalam penelitian ini adalah gangguan sirkulasi ekstrimitas seperti bengkakbengkak pada kaki pasien saat bersamaan dengan menggunakan OAT. Walaupun tidak ada referensi yang mengatakan bahwa bengkak kaki dapat dialami sebagai efek samping dari OAT, namun salah satu partisipan (P3) mengatakan bahwa penderita mengalami sejak awal pengobatan. Namun hal ini bisa saja asumsi dasar dikarenakan peneliti tidak mengkaji riwayat penyakit terdahulu yang bisa saja merupakan penyakit terdahulu atau penyakit yang muncul besertaan dengan penyakit TB Paru, sehingga belum dapat mengidentifikasi kebenaran bahwa bengkak ini termasuk efek samping dari penggunaan OAT.

Menurut Rajakumar \& Rosenberg (2008) bengkak kaki atau edema bisa saja terjadi pada penderita $\mathrm{TB}$, namun lebih spesifiknya bengkak kaki ini akan menyerang penderita TB Paru Monoarthritis, karena penderita dengan arthritis tuberkulosis dapat mengalami bengkak dikarenakan adanya hipertrofi sinovial dan cairan sinovial atau sinovium serta kadar protein yang telah lama bertahan dalam tubuh sebelum terdiagnosa penyakit lainnya sehingga perlu diukur glukosa cairan sinovial dan kadar protein saat awal penentuan diagnosa penyakit. ${ }^{16}$

Bila nantinya efek samping positif dan efek samping negatif membuat keadaan penderita dalam pengobatan dan perawatan yang lebih lama menimbulkan 
efek samping yang semakin signifikan dan berat, maka pasien perlu dirujuk dan dilakukan pemeriksaan lebih lanjut serta perlu dilakukan pemantauan laboratorium secara rutin pada penderita dengan dibantu pengawasan keluarga dan tim medis.

\section{SIMPULAN}

Berdasarkan hasil penelitian yang telah dilakukan dengan menggunakan studi kualitatif yaitu pendekatan fenomenologi tentang pengalaman keluarga merawat penderita TB Paru yang dianalisis menggunakan metode Milles dan Hauberman, informasi atau data yang digali melalui in-depth interview terhadap 4 orang partisipan sehingga didapatkan tiga tema yang telah terindenfikasi yaitu persepsi keluarga bahwa TB merupakan penyakit yang berkepanjangan dan mudah menular, pengalaman keluarga yang positif, dan efek samping yang berdampak pada multisistem.

1. Persepsi keluarga bahwa TB merupakan penyakit yang berkepanjangan dan mudah menular yaitu adanya keyakinan bahwa batuk berkepanjangan merupakan gejala awal dari TB, persepsi bahwa TB merupakan penyakit yang menular, respon negative yang diberikan lingkungan sekitar mengenai penderita dan tidak ada aspek dukungan sosial dari lingkungan sekitar mengenai penderita.

2. Pengalaman keluarga yang positif ialah perasaan takut anggota keluarga akan tertularnya penyakit yang sama, peran keluarga dan lingkungan dalam proses perawatan mentransformasikan bentuk usaha penyembuhan dan minimalnya hambatan yang dirasakan keluarga.

3. Efek samping yang berdampak pada multisistem yaitu adanya gangguan rasa nyaman, perubahan berat badan, peningkatan nafsu makan, perubahan warna urin dan gangguan sirkulasi ekstrimitas.
1. Untuk pihak keluarga dengan penderita TB Paru sebaiknya dapat mendampingi penderita dalam proses pengobatan dan perawatan baik dirumah maupun di Unit Pelayanan Kesehatan Paru. Keluarga diharapkan memperhatikan pola aktivitas dan pola hidup serta mengawasi minum obat maupun perawatan lainnya. Keluarga juga diharapkan memberikan dukungan pada penderita dan tidak menjauhi penderita TB Paru karena hal tersebut dalam menghambat proses kesembuhan.

2. Untuk tenaga kesehatan diharapkan mampu memahami pengalaman keluarga karena penelitian mengenai pengalaman keluarga dapat menjadi landasan untuk dapat memberikan mekanisme koping yang baik dari tenaga kesehatan sendiri. Tenaga medis berperan penting dalam memberikan informasi dalam bentuk edukasi maupun penyuluhan yang bertujuan membantu keluarga dalam proses perawatan dan pengobatan penderita TB Paru.

3. Untuk peneliti selanjutnya diharapkan membahas lebih dalam terkait pengalaman keluarga baik secara lingkungan maupun sosial dan budaya. Peneliti selanjutnya juga perlu melakukan latihan yang cukup sebelum melakukan wawancara mendalam kepada informan karena informan memiliki karakteristik yang berbedabeda. Latihan ini dilakukan untuk mencegah dan mengantisipasi hambatan-hambatan yang ditemukan dalam proses wawancara dilapangan.

\section{SARAN}

DAFTAR PUSTAKA 
1. World Health Organisation. (2017). Global Tuberculosis Report.

2. Dai, L., \& Wang, L. (2015). Review of Family Functioning. Open Journal of Social Sciences, 3, 134-141.

3. Saryono. (2011). Metodologi Penelitian Kualitatif Dalam Kesehatan. Yogyakarta: Nuha Medika.

4. Wahyuni., Indarwati., \& Sugiharto, A. (2015). Study of Perception, Knowledge of Prevention of Disease Transmission in Health Center. PROFESI Vol. 12 No 2, 4-7.

5. Kementerian Kesehatan Republik Indonesia. (2017). TUBERKULOSIS (TB). www.kemkes.go.id. Diakses pada tanggal 30 September 2018.

6. Jaji. (2010). Prevention of Transmission Efforts Tuberculosis (TB) Pulmonary in The Other Family Members in Working Area of Sidorejo Health Center Pagaralam Year 2010. Jurnal Ilmu Kesehatan Masyarakat Vol. 1 No 03, 183-186.

7. Wahyudi, E. (2010). Hubungan Pengetahuan, Sikap dan Motivasi Kader dengan Penemuan Suspek Tuberculosis Paru di Puskesmas Sanankulo. Unpublished M.Biomed Tesis. Universitas Sebelas Maret Surakarta.

8. Nurhidayati, I., \& Fitrianingrum, M. (2016). Perawatan Kesehatan Masyarakat pada Keluarga dengan Tuberkulosis (TBC) di Kabupaten Klaten: Study Fenomenologi. CENDEKIA UTAMA Jurnal Keperawatan dan Kesehatan Masyarakat Vol. 2 No 4, 33-38. ISSN: 2252-8865.

9. Hendiani, N., Sakti, H., \& Widayanti, C.G. (2014). Hubungan antara Persepsi Dukungan Keluarga sebagai Pengawas Minum Obat dan Efikasi Diri Penderita Tuberkulosis di BKPM Semarang. Jurnal Psikologi Undip Vol. 13 No 1, 87-89.

10. Sedjati, F. (2013). Hubungan Antara Efikasi Diri Dan Dukungan Sosial
Dengan Kebermaknaan Hidup Pada Penderita Tuberkulosis Paru Di Balai Pengobatan Penyakit Paru-Paru (BP4) Yogyakarta. Empathy Jurnal Fakultas Psikologi Vol 2 No 1, 8-12.

11. Purwanto, N.H. (2014). Hubungan antara Sikap dengan Perilaku Keluarga Tentang Pencegahan Penyakit Menular Tuberkulosis. Jurnal Keperawatan \& Kebidanan. Stiket Dian Husada Mojokerto. Hal: 75-77

12. Sari, I.D., Yuniar, Y., \& Syaripuddin, M. (2014). Monitoring Study on The Side Effect of TB Drugs Therapy FCD Category 1 in Banten and West Java Province. Media Litbangkes Vol. 24 No 1, 28-35.

13. Puspita, E., Christianto, E., \& Yovi, I. (2016). Gambaran Status Gizi pada pasien Tuberkulosis Paru (TB Paru) yang Menjalani Rawat Jalan di RSUD Arifin Achmad Pekanbaru. JOM FK Vol. III No. 2, 2-11.

14. Perkumpulan Dokter Paru Indonesia (PDPI). (2011). Pedoman Penatalaksanaan TB (Konsensus TB). Perhimpunan Dokter Paru Indonesia.

15. Wiyati, T., Irawati, D., \& Budiyono, I.I. (2014). Studi Efek Samping Obat dan Penanganannya pada pasien TB Paru di Puskesmas Melong Asih. JSTFI Indonesian Journal of Pharmaceutical Science and Technology Vol. III No 1, 26-29.

16. Rajakumar, D., \& Rosenberg, A.M. (2008). Mycobacterium Tuberculosis Monoarthritis in a Child. Pediatric Rheumatology, 1-5. 